\title{
FOPED - Formação de Professores em TIC na Educação e em EaD
}

\author{
Ednei Nunes de Oliveira
}

\author{
Diretoria de Educação a Distância \\ Universidade Federal da Grande Dourados (UFGD) \\ 79803-040 - Dourados - MS - Brasil \\ edneioliveira@ufgd.edu.br
}

Resumo: Os principais objetivos do Grupo de Pesquisa FOPED - Formação de Professores em TIC na Educação e em EaD dizem respeito ao desenvolvimento de práticas interdisciplinares na formação de professores e ao aprofundamento da reflexão-ação nesse campo. Nesse sentido, o grupo se propõe a investigar e estudar as dimensões teórico-metodológicas que subjazem os processos de formação de professores para o uso de Tecnologias de Informação e Comunicação (TIC) aplicadas na educação presencial e na modalidade a distância, como também sobre os processos e paradigmas de formação de professores, nessas modalidades, considerando o desenvolvimento do trabalho docente em contextos distintos $e$ as interferências das TIC na prática docente. Dentre as dimensões contempladas pelos estudos, encontram-se as relativas à formação inicial e continuada dos professores em seus diferentes processos, o papel da relação universidadeescola, as questões relativas à identidade profissional e aos saberes docentes, a formação do professor, os processos de formação e sua relação com as TIC e com a EaD. Atualmente, estão envolvidos com o FOPED desde pesquisadores que já desenvolvem trabalhos em linhas de pesquisa do grupo até estudantes iniciados em atividades de pesquisa e iniciação docente na área da Informática na Educação, como também docentes e técnicos que iniciaram suas pesquisas no primeiro semestre de 2014. Todos os participantes possuem vinculação direta e indireta com instituições de ensino básico e superior que desenvolvem atividades na modalidade educacional a distância ou atividades que envolvem o uso de TIC na educação. Os principais trabalhos desenvolvidos dizem respeito ao processo de implantação da Educação a Distância na UFGD e à formação inicial e continuada de docentes para atuarem na EaD/UFGD como também de técnicos para desenvolverem suporte tecnológico no uso e manipulação do Ambiente Virtual de Aprendizagem (AVA) Moodle. 